Bird Conservation International (2002) 12:19-33. (C) BirdLife International 2002

DOI: $10.1017 /$ S0959270902002022 Printed in the United Kingdom

\title{
The Great Bustard Otis tarda population in Morocco 1998-2001
}

\author{
JOACHIM HELLMICH and YOUSSEF IDAGHDOUR
}

\begin{abstract}
Summary
The Moroccan population of Great Bustard Otis tarda was surveyed in the four years 1998-2001. Highest numbers were counted in December 1998 (21 males, 62-65 females, four first-year males: total c. 90) and March 2001 ( 15 males, 60-66 females, four first-year males: total 75-81). Combining enquiry results from local people with these data, the population size for spring is estimated at 92-111 individuals, and 117-133 for winter. Reproduction is confirmed. Threats to the population include illegal hunting, habitat loss through agricultural intensification (irrigation, use of pesticides) and infrastructural changes (construction of a motorway and a powerplant), disturbance, and accidents at powerlines and antennas. Several conservation measures are suggested: cease hunting; maximize the attention given to display sites; encourage villagers to carry out "Great Bustard-friendly" land use and adapt animal stocks to the carrying capacity of their regions; clarify the situation of genetic exchange between Spanish and Moroccan populations; study movements between the Moroccan sites; monitor the size and trends of the most important subpopulations; and conduct education campaigns in schools and increase public awareness among adults.
\end{abstract}

\section{Introduction}

According to ornithological handbooks (Glutz et al. 1973, Cramp and Simmons 1980, Hollom et al. 1988, Potapov and Flint 1989) and the summarizing publication of Johnsgard (1991), on the African continent Great Bustard Otis tarda breeds only in Morocco. Pineau and Giraud-Audine (1977) knew of two Great Bustard groups existing south of Tangier and north of Larache and subsequently stated that the species still existed in the Habt (Pineau and GiraudAudine 1979). Thevenot et al. (1982) reported the existence of Great Bustards in the Tangier region, the Rharb and "le Moyen Sebou". The most recent count stemmed from the year 1982 (Goriup 1983) when 57 Great Bustards were found in the plains south of Tangier. Based on this information, Collar (1985) estimated that the Moroccan population consisted of "some 100 Great Bustards". This mid-1980 figure has been used subsequently (e.g. Urban et al. 1986, Hidalgo de Trucios 1990, Del Hoyo et al. 1996) without any further changes. At the end of the 1990s Baouab (undated) fixed the numbers at 50100 individuals and classified the species as "on the way to extinction". In Morocco Great Bustard is totally protected by law.

It has long been obvious that the status of Great Bustard in Morocco was in urgent need of re-evaluation. In order to achieve this, three surveys were con- 
ducted in 1998 in areas where the most recent observations had been made (see Hellmich 1999). More surveys were carried out in the springs of 1999 (with the participation of two foreign researchers; see Alonso et al. 2000) and 2000 (the latter just to assess the presence of males in the known display sites) as well as several brief visits. At the end of March 2001 a complete census of the region was conducted.

\section{Materials and Methods}

Within an area of roughly 4,200 $\mathrm{km}^{2}$ between Tangier, Kenitra and Sidi Kacem, 29 sites known or suspected of holding Great Bustards were visited during the surveys. According to topographical characteristics the visited sites were arranged into eight groups (A to H: see Figure 1) herein referred to as "areas" which were subdivided into "sites". For reasons of security, in the text we do not give the exact locations of the flocks found.

Visits were made on the following dates: 22-27 March 1998 (6 days), 9-21 July 1998 (13), 24 December 1998 to 1 January 1999 (9), 11-13 March (3), 2328 March 2000 (6), and 17-25 March 2001 (9). Including time spent during brief visits (one or two days) in June, October, and November 2000, as well as January 2001, we were in the region for 53 days. Surveys and censuses were carried out in the morning and from late afternoon to evening. The exact times varied according to the season: 05h $55-12 \mathrm{hoo}$ and $15 \mathrm{ho5}_{-18 \mathrm{~h}} \mathrm{O}$ (spring), 05hoo-11hoo and $16 \mathrm{~h}_{30}-19 \mathrm{~h}_{30}$ (summer) and o7h $30-12 \mathrm{~h} 20$ and $14 \mathrm{~h}_{50}-$ 17 h2o (winter). During these hours Great Bustards were most active, and meteorological phenomena such as heat haze did not obstruct the identification of the birds' sex and age even at large distances (see also Hellmich 1987, 1991a, Alonso et al. 1990a).

The area was prospected using a single four-wheel-drive car (two cars in the 2001 March census) following the network of existing roads and tracks, and scanning from suitable vantage points with $8 \times 56$ and $25 \times 8$ o binoculars or a $20-60 \times 77$ telescope, the last two tripod-mounted. If a flock was found we recorded date, hour (in GMT), geographical coordinates in WGS84 datum, number of unsexed/ unaged individuals, number of adult males, subadult (two- or three-year-old) males, first-year males, and females, predominant activity in the flock, and habitat type in use. Additionally, notes were made on indirect evidence that indicated the presence of Great Bustards, e.g. footprints or feathers lost by moulting or when preening, as well as on possible dangers or sources of disturbance to the birds. Mapping of the locations where flocks had been found was done on maps of 1:100,000 and 1:50,000 (Moroccan Ministry of Agriculture 1942-1996). Geographical coordinates were obtained using GPS navigators, versions Garmin II plus and III plus.

During searches for Great Bustards local people were asked about the presence of the species in the area. If several persons coincided in their statements, the information was used for the final estimation of the number of Great Bustards living in the area. It became clear that all oral information had to be cross-checked when "Great Bustards" shown to us proved to be Grey Herons Ardea cinerea! 


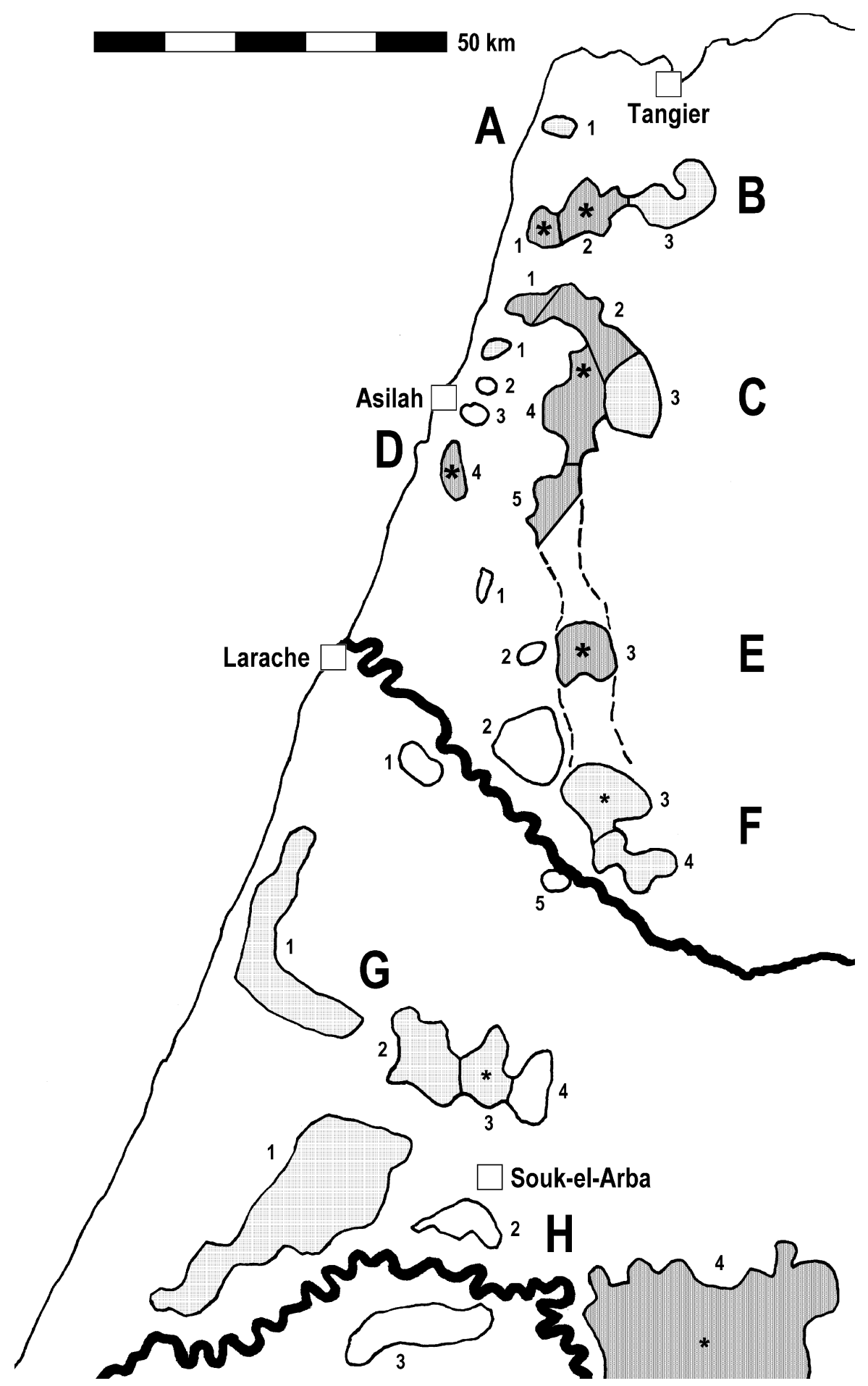

Figure 1. Distribution of Great Bustard in Morocco. Capital letters = areas, numbers = sites,$~^{*}=$ display supposed, dark grey $=$ Great Bustards seen, light grey $=$ Great Bustards reported, no hatching $=$ no Great Bustards reported in last ten years. 
Table 1. Sex and age classes from censuses of Great Bustard in Morocco, in March 1998-2001. Data for March 1999 are taken from ALONSO et al. (2000).

\begin{tabular}{lcclllll}
\hline & $\begin{array}{l}\text { Total } \\
\text { males }\end{array}$ & $\begin{array}{l}\text { Adult } \\
\text { males }\end{array}$ & $\begin{array}{l}\text { 2nd-3rd } \\
\text { year } \\
\text { males }\end{array}$ & $\begin{array}{l}\text { 1st year } \\
\text { males }\end{array}$ & Females & TOTAL & Sex-ratio \\
\hline March 1998 & 17 & 5 & 12 & 0 & 49 & 66 & $2: 9$ \\
March 1999 & 15 & 10 & 3 & 2 & 49 & 64 & $3: 3$ \\
March 2000 & 6 & 6 & 0 & 0 & 24 & 30 & $4: 0$ \\
March 2001 & 15 & 7 & 4 & 4 & $60 / 66$ & $75 / 81$ & $4: 0 / 4: 4$ \\
\hline
\end{tabular}

\section{Results}

\section{Demographic data}

Most Great Bustards (90 individuals) were seen in winter 1998, followed by the spring 2001 result of $75-81$ birds (Table 1 ). The latter census also gave the highest number of females recorded (66). Males were less numerous than females, the maximum seen being 25 in December 1998. The only summer visit gave the lowest number of birds seen: 28 , among which only 10 were females. Up to four first-year males were found. In the December 1998 survey three birds remained unsexed; very probably these were females, which would change the total and the area sex ratio only slightly.

The 90 birds counted during the December 1998 survey set the minimum for the population for 1998 (Hellmich et al. undated). Even though in 2001 one area (B1/B2) had fewer birds than in 1998 or 1999, the total number of Great Bustards found during the March 2001 census was higher than that obtained in previous springtime surveys, and with a minimum of 75 Great Bustards (and probably more than 80) came quite close to the December count. This was mainly due to the facts that Great Bustards were found in two areas where no birds had been seen before in springtime $\left(\mathrm{E}_{3}\right.$ and $\left.\mathrm{H}_{4}\right)$, or winter $\left(\mathrm{H}_{4}\right)$, that two teams were involved and that larger areas than before were visited.

First-year males were found in four out of six surveys and censuses: July 1998 (one bird); December 1998 (four); March 1999 (two); and March 2001 (four). If the existence of four first-year females is assumed for March 2001 (the same number as in first-year males), then at least eight first-year birds were present, giving (based on 56-62 females) a reproductive success of 14.3-12.9 chicks per 100 females or $9.9-10.7 \%$ of chicks in the population.

\section{Distribution and movements}

The birds were found at nine sites in five areas (Figure 1: B, C, D, E, H) between sea level and $200 \mathrm{~m}$. The area of distribution is limited by the Atlantic Ocean in the west, by the western part of the Rif mountain chain in the east, and by the Sebou River in the south. Until the end of 2000, we found Great Bustards only north of the Loukkos River valley between $35^{\circ} 40^{\prime} \mathrm{N}$ and $35^{\circ} 10^{\prime} \mathrm{N}$. However, oral information had extended the area of (probable) distribution notably towards the 
south to the region of the middle course of the Sebou River, and in the year 2001 several Great Bustards were detected there, too.

In 2001, as in previous visits (see Hellmich 1999, Hellmich and Idaghdour 2001), the known sites in areas B, C, and D held females and displaying males. Area E, where footprints, faeces and feathers were found in March 1998, where nine males were seen in July 1998 and where local people repeatedly reported the presence of Great Bustards, proved to be a display site. In 2001, birds at this site were observed flying in southerly and south-easterly directions, which corroborated our earlier assumption that it is connected to the more southern site F3. In an earlier paper (Hellmich 1999) based on survey results and on information of local people, we speculated that there might be another display site in the hills of $\mathrm{F}_{3}$ whose existence was not confirmed then. The $\mathrm{E}_{3}$ display site found during the March 2001 census lies less than $20 \mathrm{~km}$ north of the suspected area. At site $\mathrm{H}_{4}$, since the first survey in December 1998 we had obtained positive reports of the presence of Great Bustards by several local people. In spite of this no birds were seen during all but the last visit, when females were found but no displaying males, even though in December 1998 and March 2001 villagers had given us clear descriptions of courtship display behaviour. This site had rather large dimensions: Great Bustards were seen on some $30 \mathrm{~km}^{2}$, but the suitable area seemed to amount to far more than $200 \mathrm{~km}^{2}$. It is likely therefore that one could expect to find more Great Bustards in future spring censuses in $\mathrm{H}_{4}$ (as well as in areas unsurveyed to date).

The distances between the centres of the sites with displaying males were 16 $\mathrm{km}$ ( $\mathrm{B}_{2}$ to $\left.\mathrm{C}_{2}\right),{ }_{16} \mathrm{~km}\left(\mathrm{C}_{2}\right.$ to $\left.\mathrm{D}_{4}\right)$, and $30 \mathrm{~km}\left(\mathrm{D}_{4}\right.$ to $\left.\mathrm{E}_{3}\right)$. From the latter site to the now southernmost Great Bustard site ( $\mathrm{E}_{3}$ to $\left.\mathrm{H}_{4}\right)$ we measured some $90 \mathrm{~km}$.

There are indications of successful breeding by Great Bustards since our July 1998 survey. The exact location of two nests is known, and nesting localities were shown to us by local people at two more sites. Observations of first-year birds were made at five sites: $\mathrm{B}_{2}, \mathrm{C}_{1}, \mathrm{C}_{2}, \mathrm{C}_{4}, \mathrm{E}_{3}$.

At $\mathrm{C}_{1}$ birds were present between October and January, but never between February and October, so this area may be considered a wintering area. Very probably, the same holds for $\mathrm{C}_{5}$ where Great Bustards were found only in December, indicating that there are movements between sites. In fact, 17 flocks were seen flying from one site to another, but only on three occasions were birds seen moving from one area to another. Enquiries produced a somewhat fuller picture of possible movements, but in most cases the informants only saw the birds in flight without knowing where they came from or where they were moving to.

\section{Living conditions for Great Bustards in the areas}

Area A has only one site, the airport and its surroundings to the south. Even if in the past Great Bustards were occasionally seen in this area (in 1997 a Great Bustard collided with a plane at the airport), no permanent presence has been reported. At present the site is now an industrial area.

In area $\mathrm{B}$, sites $\mathrm{B} 1$ and part of $\mathrm{B} 2$ are periodically flooded and can only be used for grazing, which then exerts high pressure on wildlife. The rest of the area is 
used for agriculture and grazing. The conditions for Great Bustards have suffered notable changes in recent years. In a well-defined area in Bi seven males - two of them displaying - were present in 1998. This "traditional" display area, whose existence was first reported by Goriup (1983), seems not to be used any more. During the present census, males were found more than $2 \mathrm{~km}$ east and westsouth-west from this area. Females were at the same distance from the former display area. The change seems to be attributable to the permanent presence since January 2000 of a shepherd with animals $150 \mathrm{~m}$ south of the then main display point. We met this shepherd in March 2000, and he told us that he used to hunt Great Bustards there. Hunting is reported from B2, also. In the future, two fundamental changes will have additional negative effects on this site: the northern section of the Rabat-Tangier motorway (Direction des Routes et de la Circulation Routière undated) will cross $\mathrm{B}_{1}$ exactly where at present the adult male was found displaying, and a 350-400 megawatt combined-cycle power plant will be constructed at the mouth of the Tahadart River (Anonymous 2000). A shepherd reported that a dead Great Bustard had been found under the radio antennas in B2.

Area $C$ is separated from area B by a hill range. Site $C_{1}$ is an autumn-andwinter area. In spring the Great Bustards mainly move to the hills and valleys of $\mathrm{C}_{2}$, where displaying males were found. In spring some females lived in $\mathrm{C}_{4}$, and in winter some females were found in $\mathrm{C}_{5}$. As the main human activities in this area are agriculture and cattle breeding, and as the whole area is inaccessible for motor vehicles during rainy periods, at the moment drastic negative changes for the species are not expected. However, farmers are beginning to use chemicals (backpack spraying devices are used) to protect crops against pests. At least one case of hunting has been recorded.

Area D (four sites) is situated in intensively used farmland. In $\mathrm{D}_{4}$, small properties with a wide variety of different crops and unused fallow areas form a landscape mosaic and guarantee food for the Great Bustards, but year-round presence of small flocks of sheep and goats as well as cattle (singly or in small groups) together with the herdsmen and the ever-present dogs cause a lot of disturbance. The site is occupied by Great Bustards from February to July, display has been seen annually, nesting is reported, and offspring have been observed, but no Great Bustards were present during winter. In March 2001, apart from 24 females we found three males of different age: one adult, one twoor three-year-old and one first-year, which during the census was still with a female (presumably its mother). In the valley bordering the site, the Moroccan "Ministère de l'Equipment" is constructing the motorway section between the already existing Sidi el-Yahmani exit and Tangier (see site B1). Great Bustards were repeatedly found at points less than $300 \mathrm{~m}$ from this future "autoroute", and the display point of the years 1998 and 1999 was $950 \mathrm{~m}$ from it. The points where an adult male displayed in 2000 and 2001 were some $500 \mathrm{~m}$ further from the autoroute than in previous years. Most locations where females were seen in the past were closer to the future motorway than during the 2001 census. We are tempted to speculate that these changes are due to evasive movements caused by the increasing human activities during the preparation and initiation of the construction.

Area E is used intensively by agriculture, too. Only site E3 holds Great Bus- 
tards. Recent visits showed that it seems to be at risk from increasing cattle breeding. Two houses that were vacant in March 1998 have been changed into large stables, and a track some $6 \mathrm{~km}$ long and $6 \mathrm{~m}$ wide now facilitates easy access to the area. Rural development plans for this area have to be assessed urgently. A strong incidence of hunting has been reported (5 or 6 birds killed in 2000).

The five sites of area $\mathrm{F}$ are situated in the Loukkos valley and in the hills east of it. $F_{1}, F_{2}$ and $F_{5}$ are irrigated (occasional presence of Great Bustards has been reported for $\mathrm{F}_{5}$ ). $\mathrm{F}_{3}$ and $\mathrm{F}_{4}$ show a high impact by permanent flocks of sheep and goats and by intensive agriculture on large areas of orange trees and sugar-cane. Shepherds at $\mathrm{F}_{4}$ repeatedly told us that Great Bustards were found dead after collisions with powerlines. No hunting has been reported to date.

Area $G$ is at the limit of the extended irrigated surfaces in the Loukkos valley and parts of site $G_{1}$ are irrigated too. In site $G_{3}$ monocultures are dominant and grazing is almost non-existent. Hunting has played an important role in sites G2 and $G_{3}$, at least in the past. No Great Bustards were reported in the last five years in G1. Local people say that Great Bustards began to disappear with the implementation of the irrigation schemes.

Area $\mathrm{H}$ is the most extensive area. Sites $\mathrm{H}_{1}, \mathrm{H}_{2}$ and $\mathrm{H}_{3}$, which are in the Sebou river valley, are largely converted to irrigation. $\mathrm{H}_{4}$ is mainly a hill area but despite high-intensity agriculture and grazing the large size of the area still provides good conditions for Great Bustards. General access to site $\mathrm{H}_{4}$ is rather easy but once off the main roads moving around with motor vehicles is quite difficult. Hunting seems to play an important role (see also footnote in Alonso et al. 2000).

\section{Discussion}

\section{The population estimate}

Spring totals have been stable since 1998 or even shown a slight increase in numbers (Table 2), owing to stable male numbers and higher female numbers. However, this may be biased by the different levels of effort during the visits. The time spent visiting the Great Bustard region differed widely from one year to the next. The surveys in 1998 and 1999 were done with only one car, lasting six and three days respectively. In 2001 two teams used two cars over nine days. In the spring surveys of 1998 and 1999 only areas north of Souk-al-Arba were visited, whereas in 2001 areas down to the Sebou river were censused. So comparisons between years are not very reliable.

The overall sex ratio of birds seen in March 2001 (1:4.0-4.4) was biased towards females even more than in previous visits (Table 2). This may have had different causes. Perhaps we did not detect all males: this especially holds for the $\mathrm{H}_{4}$ area (only 5-11 females found). A display site with at least one or two males might be there, although this would only bring the sex ratio to (a still largely female-biased) 1:3.5-3.9. Even this improved value is far from the March values (between 1.02 and 2.21) known from other Great Bustard regions (Alonso et al. 1990a,b,c, 1995, Lucio and Purroy 1990, Hellmich 1990a,b). In a population with 6o-66 females in spring and a sex ratio between 1.5 and 1.8 there should be between 33 and 44 males instead of 15 . So the possibility remains that the bias is due to male (i.e. trophy) hunting. 
Table 2. Results of Great Bustard surveys and censuses in Morocco, 1998-2001. Data for March 1999 are taken from ALONSO et al. (2000)

\begin{tabular}{|c|c|c|c|c|c|c|c|c|}
\hline MARCH 1998 & $\begin{array}{l}\text { Not } \\
\text { sexed/ } \\
\text { aged }\end{array}$ & $\begin{array}{l}\text { Adult } \\
\text { males }\end{array}$ & $\begin{array}{l}\text { 2nd/3rd } \\
\text { year } \\
\text { males }\end{array}$ & $\begin{array}{l}\text { 1st } \\
\text { year } \\
\text { males }\end{array}$ & Males & Females & TOTAL & $\begin{array}{l}\text { Sex- } \\
\text { ratio }\end{array}$ \\
\hline $\begin{array}{l}\mathrm{B}_{1} / \mathrm{B}_{2} \\
\mathrm{C}_{1}\end{array}$ & & 2 & 5 & & 7 & 11 & 18 & $1: 6$ \\
\hline $\begin{array}{l}\mathrm{C}_{2} / \mathrm{C}_{4} \\
\mathrm{C}_{5}\end{array}$ & & 2 & 7 & & 9 & 17 & 26 & $1: 9$ \\
\hline $\begin{array}{l}\mathrm{D}_{4} \\
\mathrm{E}_{3}\end{array}$ & & 1 & & & 1 & 21 & 22 & $21: 0$ \\
\hline $\begin{array}{l}\text { TOTAL } \\
\text { MARCH } 1998\end{array}$ & $\mathrm{o}$ & 5 & 12 & 0 & 17 & 49 & 66 & $2: 9$ \\
\hline JULY 1998 & $\begin{array}{l}\text { Not } \\
\text { sexed/ } \\
\text { aged }\end{array}$ & $\begin{array}{l}\text { Adult } \\
\text { males }\end{array}$ & $\begin{array}{l}\text { 2nd/3rd } \\
\text { year } \\
\text { males }\end{array}$ & \multicolumn{2}{|c|}{ Ist year males } & Females & TOTAL & $\begin{array}{l}\text { Sex- } \\
\text { ratio }\end{array}$ \\
\hline $\begin{array}{l}\mathrm{B}_{1} / \mathrm{B}_{2} \\
\mathrm{C}_{1}\end{array}$ & & & & 1 & 1 & 3 & 4 & $3: 0$ \\
\hline $\begin{array}{l}\mathrm{C}_{2} / \mathrm{C}_{4} \\
\mathrm{C}_{5}\end{array}$ & & 7 & & & 7 & 2 & 9 & $0: 3$ \\
\hline $\mathrm{D}_{4}$ & 2 & 1 & & & 1 & 5 & 6 & $5: 0$ \\
\hline $\mathrm{E}_{3}$ & & 9 & & & 9 & & 9 & $0: 0$ \\
\hline TOTAL JULY 1998 & 2 & 17 & o & 1 & 18 & 10 & 28 & o:6 \\
\hline DECEMBER 1998 & $\begin{array}{l}\text { Not } \\
\text { sexed/ } \\
\text { aged }\end{array}$ & $\begin{array}{l}\text { Adult } \\
\text { males }\end{array}$ & $\begin{array}{l}\text { 2nd/3rd } \\
\text { year } \\
\text { males }\end{array}$ & \multicolumn{2}{|c|}{ 1st year males } & Females & TOTAL & $\begin{array}{l}\text { Sex- } \\
\text { ratio }\end{array}$ \\
\hline $\begin{array}{l}\mathrm{B}_{1} / \mathrm{B}_{2} \\
\mathrm{C}_{1} \\
\mathrm{C}_{2} / \mathrm{C}_{4} \\
\mathrm{C}_{5} \\
\mathrm{D}_{4} \\
\mathrm{E}_{3}\end{array}$ & 3 & $\begin{array}{r}5 \\
3 \\
13\end{array}$ & & $\begin{array}{l}3 \\
1\end{array}$ & $\begin{array}{r}8 \\
4 \\
13\end{array}$ & $\begin{array}{r}27 \\
5 \\
19 \\
11\end{array}$ & $\begin{array}{l}35 \\
32 \\
0 \\
0\end{array}$ & $\begin{array}{l}3: 4 \\
1: 3 \\
1: 5\end{array}$ \\
\hline $\begin{array}{l}\text { TOTAL } \\
\text { DECEMBER } 1998\end{array}$ & 3 & 21 & $\mathrm{o}$ & 4 & 25 & 62 & 90 & $2: 5$ \\
\hline MARCH 1999 & $\begin{array}{l}\text { Not } \\
\text { sexed/ } \\
\text { aged }\end{array}$ & $\begin{array}{l}\text { Adult } \\
\text { males }\end{array}$ & $\begin{array}{l}2 \mathrm{nd} / 3 \mathrm{rd} \\
\text { year } \\
\text { males }\end{array}$ & \multicolumn{2}{|c|}{ 1st year males } & Females & TOTAL & $\begin{array}{l}\text { Sex- } \\
\text { ratio }\end{array}$ \\
\hline $\begin{array}{l}\mathrm{B}_{1} / \mathrm{B}_{2} \\
\mathrm{C}_{1}\end{array}$ & & 5 & 1 & & 6 & 8 & 14 & $1: 3$ \\
\hline $\begin{array}{l}\mathrm{C}_{2} / \mathrm{C}_{4} \\
\mathrm{C}_{5}\end{array}$ & & 4 & 1 & 1 & 6 & 10 & 16 & $1: 7$ \\
\hline $\begin{array}{l}\mathrm{D}_{4} \\
\mathrm{E}_{3}\end{array}$ & & 1 & 1 & & 2 & 22 & $\begin{array}{r}24 \\
0\end{array}$ & $11: 0$ \\
\hline $\begin{array}{l}\text { TOTAL } \\
\text { MARCH } 1999\end{array}$ & 0 & 10 & 3 & 2 & 15 & 49 & 64 & $3: 3$ \\
\hline
\end{tabular}


Table 2. Continued

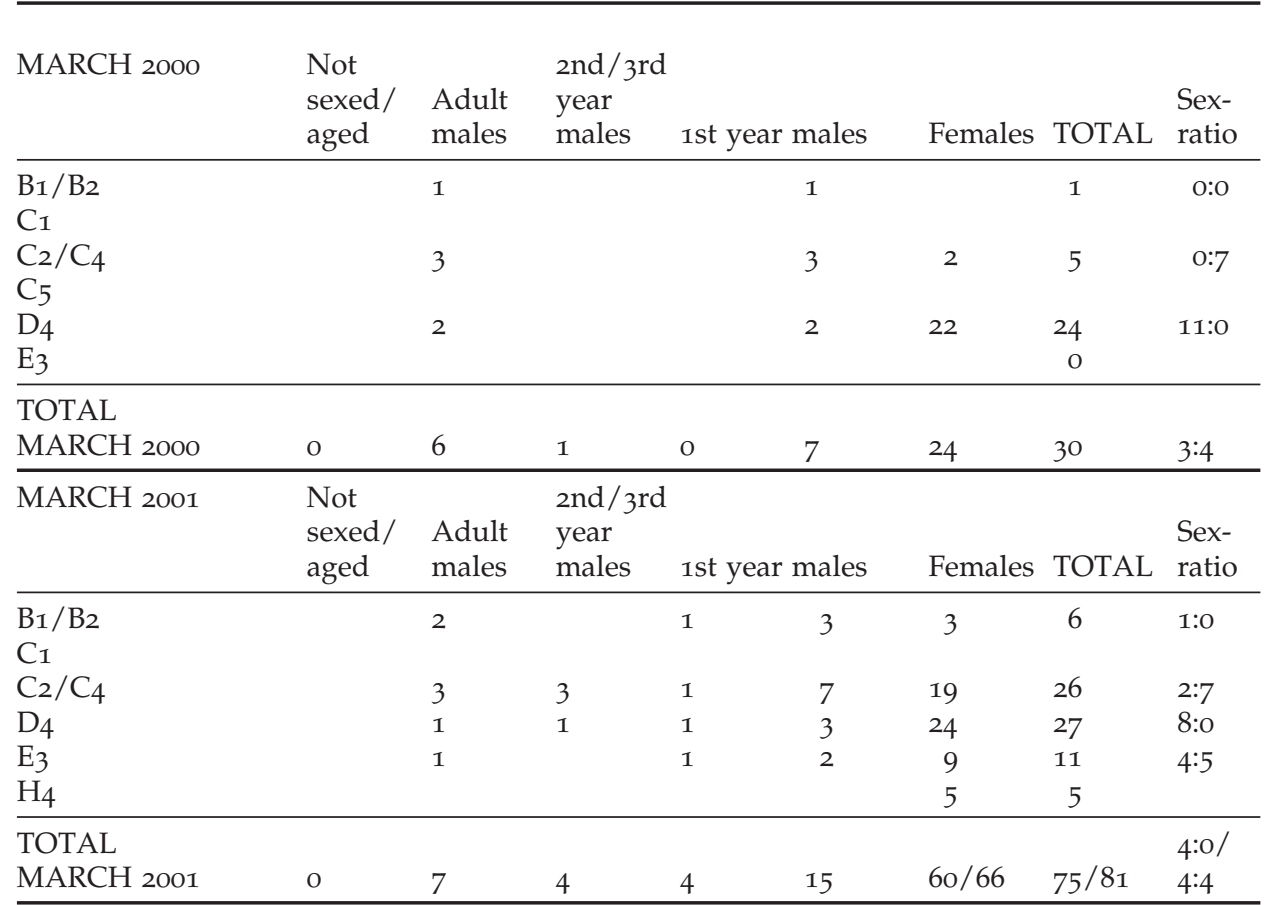

Nevertheless, there may be some movement, especially among males, to regions still undetected in Morocco, or even an interchange of individuals with populations in southern Spain. We pointed out in an earlier report (Hellmich 1999) that the closest Spanish site "La Janda", west of Tarifa, is less than $70 \mathrm{~km}$ from the northernmost Moroccan breeding area (B), a distance that Great Bustards are able to fly in less than an hour (J. Hellmich unpubl.). However, despite a long tradition of birdwatching at Gibraltar and Tarifa, there are no reports at all of Great Bustards crossing the Straits of Gibraltar, and only once was the species sighted at the "Rock" (Cortes et al. 1980) and hunted near it (Telleria 1981). We asked the SEO (Spanish Ornithological Society) internet chat forum if any participant had seen Great Bustards crossing the Straits, which produced two negative answers (F. Montoya, COCN Tarifa pers. comm., A. Paterson, GOS pers. comm.). Until Great Bustards are marked at one of the Iberian sites and afterwards seen in North Africa or vice versa, reflections on migration remain speculative, and consequently the sex ratio of the Moroccan population will remain uncertain.

In December 1998, 66 of 81 oral reports obtained by local people were considered to be valid. These indicated that more Great Bustards than those seen during the surveys might exist in northern Morocco. Reports agreed that south of the Loukkos River there should be 3-5 Great Bustards in the F 3 site, between 15 and 20 in $\mathrm{G}_{2}$ and $\mathrm{G}_{3}, 4^{-8}$ in $\mathrm{H}_{1}$, and 5-10 in $\mathrm{H}_{4}$, suggesting a population of between 27 and 43 birds based on interview results. During the March 2001 census, 97 people were asked for numbers and whereabouts of Great Bustards; 54 of them 
gave information of use for the final estimation of the actual springtime population. Such information ( 1 or 2 more Great Bustards reported than seen by us in B; 4-6 more in C; G2: plus 6; H: plus 4-10) allows us to add between 15 and 28 individuals to the figures achieved by our direct observations. The estimated December 1998 overall total therefore ranges from 117 to 133 Great Bustards, and the estimated March 2001 overall total may be calculated as between 90 and 109 Great Bustards. If area H, the "area about $80 \mathrm{~km}$ North of Meknes, southeast of Souk-el-Arba-du-Rharb" mentioned by Alonso et al. (2000), really holds about 20 birds, the total estimate may even be higher.

\section{The area of distribution}

Great Bustard sites are now situated in river valleys or in hill areas, whereas in former times border areas of lagoons also may have been inhabited (Merja Zerga close to Moulay Bouselham in area G: Bergier and Bergier (undated), the former Bouharcha lagoon in area F: pers. comm. by local shepherds). Only one display site $\left(\mathrm{B}_{1}\right)$ is in a valley, the others being found on hilltops or slopes. Wintering seems to occur mainly in the valleys (B2, $\left.\mathrm{C}_{2}\right)$, where flocks of up to 30 or more were seen.

Even if the land area on which Great Bustards were found in the last four years only totals $110 \mathrm{~km}^{2}$, the actual area used may be more than $1,000 \mathrm{~km}^{2}$ and the current "extent of occurrence" of the species in Morocco represents a total area of close to $10,000 \mathrm{~km}^{2}$. It is impossible to protect and conserve this huge area efficiently. The fragmentation of the population represents another problem. Distances between the northern areas B, C, D and E do not exceed the distance of $20 \mathrm{~km}$ found between courtship display areas and places where nests have been found in Europe (Glutz et al. 1973, Collar and Goriup 1980, Cramp and Simmons 1980, Dornbusch 1987), without any doubt there is interchange of individuals. But the $90 \mathrm{~km}$ between $\mathrm{H}_{4}$ and $\mathrm{E}_{3}$ is larger than the "normal" $60-65 \mathrm{~km}$ distances covered by Great Bustards during their dispersal movements between the natal lek area and the final site of establishment as an adult bird in European populations (Dornbusch 1987, Alonso et al. 1995, 1998). It is not known if there are any sites between $\mathrm{E}_{3}$ and $\mathrm{H}_{4}\left(\mathrm{G}_{2}, \mathrm{G}_{3}, \mathrm{G}_{4}\right.$ ?) that may be used as stepping stones. So this distance perhaps impedes the frequent interchange of birds between $\mathrm{H}_{4}$ and the other areas.

\section{Threats and the vulnerability of the population}

Hunting of the species was reported in the seventies by Pineau and GiraudAudine (1979) and later by Schollaert et al. (1994). Baouab (undated) lists "braconnage" as one of the threats. During the course of interviews with local people, it was usually mentioned that poachers had killed Great Bustards. Even if hunting is prohibited by law, in some areas it is still an important direct threat. If, for example, the adult male in $\mathrm{D}_{4}$ were to be "removed" by poaching, there would be no male of reproductive age at the site, and breeding might not occur at least until that male is replaced by another adult male. The fact that "hunters" using four-wheel-drive cars are able to penetrate even into the most remote Great Bustard areas has changed the situation for the worse. 
Agricultural activities follow seasonal patterns, the timing and sequence of which depend on the initial rainfall (in October or November) and on the amount and the temporal and spatial distribution of rain. In the short term, ploughing directly displaces the bustards from their normal haunts, while in the medium term it changes important favoured habitat types with high food availability into unfavoured ones. When late cereals and legumes are harvested, no Great Bustards are close to areas where these agricultural activities are performed or have been completed. Irrigation, widespread in the valleys of the rivers Loukkos and Sebou (sites $\mathrm{F}_{1}, \mathrm{~F}_{2}, \mathrm{~F}_{5}, \mathrm{H}_{1}, \mathrm{H}_{3}$, and in parts of $\mathrm{G}_{1}$ and $\mathrm{H}_{2}$ ), is another aspect of agricultural land use detrimental to the species. The large orange plantations and sugar-cane fields in these areas are not favourable habitats for Great Bustards.

All year round, domestic animals are numerous co-users of the Great Bustard sites. Sheep and goats, cattle, camels, horses, donkeys and mules move around in the areas that are used by the birds. During our study, the area used for grazing included stubble and fallow as well as large amounts of the area with natural vegetation (palmetto, thistles), and there was almost nowhere in which Great Bustards could avoid repeated encounters with domestic animals. The normal distance of about $300 \mathrm{~m}$ (Hellmich 1992a) to the nearest domestic animal flock or to other factors of disturbance cannot be maintained by Moroccan Great Bustards, and they make way for the intruders. This implies additional movements by the species and a loss of energy which must be compensated through supplementary food intake. Many shepherds stay in the field during the summer nights and do not return to the villages with their animals. Dogs accompanying these herdsmen and other straying dogs are frequent, and on two occasions a direct influence on Great Bustard activities was noticed. At that time of the year, Great Bustards are said to appear to feed only very early in the morning and very late in the evening. In July 1998, in spite of being in the field from the first moment of visibility to the last, we saw Great Bustards only before o7ho4 and after $18 \mathrm{~h} 34$. So, a high impact appears to be created by the competition for food with grazing domestic animals in the survey area as well as by multiple disturbances all over the region. On the other hand, Great Bustards are difficult to find in summer (May-September: Alonso et al. 1990a, Hidalgo and Carranza 1990, Hellmich 1991C).

Power lines and radio antennas can be found in almost all the Moroccan areas available for and used by Great Bustards. They contribute substantially to the mortality of the species in several countries: in Austria, Germany and Spain marking of the cables with coloured balls or spirals is done to reduce the number of accidents (Hellmich 1992a, Alonso et al. 1993, H. P. Kollar pers. comm.).

Pineau and Giraud-Audine (1979) argued that "large-scale pesticide spraying can only be detrimental" to the Great Bustards. The use of small aircraft as known from the Spanish mainland (Hellmich 1992b) was not observed during the study, but backpack spraying devices were used in area C.

All the factors listed above are known to influence the population detrimentally. An apparently high level of mortality and a reproductive success that ranges among the lowest known from other Great Bustard regions, e.g. on the Iberian Peninsula (Alonso et al. 1990a,b,c, 1995, Hellmich 1990a,b, Lucio and Purroy 1990), suggest the Moroccan population has a limited viability.

Some scattered data from references (Hartert and Jourdain 1923, Bede 1926: 
both in Collar 1985, Schollaert et al. 1994, Schollaert and Franchimont 1995, 1996, El Ghazi and Franchimont 1998-99, H. Karhu karhut@zoo-gate.fi) and our enquiry results indicate a marked decrease in the population and a notable range loss. The Moroccan springtime Great Bustard population seems to be confined to only five sites, and it is highly fragmented. At present, no fragment holds more than three adult males, and two areas only harbour a single bird (see Table 1). This makes any one of the subpopulations very vulnerable.

Hunting, habitat loss through changes in infrastructure and intensification of agriculture, disturbance by grazing, food competition with domestic animals, and accidental mortality at powerlines and antennas are the most important factors that cause low breeding success and high mortality. To guarantee the survival of the Moroccan Great Bustard population, some protection and conservation measures should be considered and implemented as soon as possible.

\section{Proposals for Action}

The following measures of protection and conservation are considered to be essential for the survival of Great Bustard in Morocco. They are based on the action plans developed for Great Bustard in Europe (Kollar 1996) and in Asia (Chan and Goroshko 1998).

Legislation Consider all Moroccan Great Bustard sites to be key sites to which maximum protection should be given. Ensure a ban on hunting, and stop illegal hunting. Train protected area staff for the needs of Great Bustard protection. Control permanently the Great Bustard areas, especially the courtship display sites between February and June. Promote international cooperation, and include Moroccan Great Bustards in the activities of the "Action Plan for the European Great Bustard" and of CMS (Convention on the Conservation of Migratory Species of Wild Animals).

Habitat management Create and/or maintain "Great Bustard-friendly" land use in Great Bustard areas (perhaps through incentives but preferably through education). Promote policies which support agricultural methods which favour Great Bustards and their habitats, e.g. conservation of fallow areas after harvest. Acquire the most important fields at key sites. Mark cables of powerlines in areas where accidental mortality at cables is high.

Species management Encourage farmers to report to the authorities when abandoned clutches are found.

Monitoring and research Study genetic structure of Moroccan Great Bustards. Clarify the situation of genetic exchange between Spain and Morocco. Use noninvasive methods when collecting samples for genetic studies. Study key sites. Promote research which is of direct application to the conservation of the species. Study space and habitat use, movements, dispersal patterns, mortality factors. Monitor numerical size and trends, and sex and age composition of the Moroccan Great Bustard population. Conduct springtime and winter censuses every year within the next 10 years. Study movements between the Moroccan sites and the 
interchange of Moroccan Great Bustards with the southern Spanish subpopulations.

Public awareness and education Create increased public awareness among adult persons about the need to protect Great Bustards and their habitats in villages close to Great Bustard areas. Conduct education campaigns in schools close to Great Bustard areas. Involve local people in conservation. Involve nongovernmental organizations (NGOs) and collaborate with governmental institutions.

\section{Acknowledgements}

We thank HRH Prince Sultan bin Abdul Aziz Al Saud for the financial support, Sheikh Mohammed bin Khalid bin Hethlain, Dr Sami Jamil Jadallah and Paul McCormick for their interest. Paul Goriup provided a map and notes about his 1982 findings. Thanks go to Bob Dawson and Damien Broderick who improved the first draft of the text and especially to Nigel Collar for his invaluable comments on the submitted paper.

\section{References}

Alonso, J. A., Alonso, J. C. and Hellmich, J. (1990a) Métodologia propuesta para los censos de avutardas. Pp. 86-98 in J. C. Alonso and J. A. Alonso, ed. Parámetros demográficos, selección de hábitat y distribución de la Avutarda (Otis tarda) en tres regiones españolas. ICONA-F.E.P.M.A. (Colección técnica).

Alonso, J. C., Alonso, J. and Martín. E. (199ob) La población de Avutardas de la provincia de Madrid. Pp. 58-72 in J. C. Alonso and J. A. Alonso, ed. Parámetros demográficos, selección de hábitat y distribución de la Avutarda (Otis tarda) en tres regiones españolas. ICONA-F.E.P.M.A. (Colección técnica).

Alonso, J. C., Alonso, J. A. and Navesco, M. A. (1990c) La población de Avutardas del área de Villafáfila y Raso de Villalpando (Zamora). Pp. 25-53 in J. C. Alonso and J. A. Alonso, ed. Parámetros demográficos, selección de hábitat y distribución de la Avutarda (Otis tarda) en tres regiones españolas. ICONA-F.E.P.M.A. (Colección técnica).

Alonso, J. C., Alonso, J. A. and Muñoz-Pulido, R. (1993) Señalización de lPneas de alta tensión para la protección de la avifauna. LPnea Valdecaballeros-Guillena. Red Eléctrica de España.

Alonso, J. C., Alonso, J. A., Martín, E. and Morales, M. (1995) Range and patterns of Great Bustard movements at Villafafila, NW Spain. Ardeola 42: 69-76.

Alonso, J. C., Alonso, J. A., Martín, E. and Morales, M. (1998) Proximate and ultimate causes of natal dispersal in the great bustard Otis tarda. Behav. Ecol. 9: 243-252.

Alonso, J. C., Lane, S. J., Dawson, R. and Idaghdour, Y. (2000) Great Bustards Otis tarda in Morocco: status in Spring 1999 and evidence of a decline in recent decades. Oryx 34: $141-146$.

Anonymous (2000) 350-400 MW combined cycle power plant for Morocco. Cogeneration and On-Site-Power Production 1 (2).

Baouab, R. E. (undated) Étude Nationale sur la Biodiversité: Oiseaux. Royaume du Maroc: Observatoire National de l'Environnement du Maroc "O.N.E.M.".

Bergier, P. and Bergier, F. (undated) A birdwatchers' guide to Morocco. Perry: Prion Ltd.

Chan, S. and Goroshko, O. A. (1998) Action plan for conservation of the Great Bustard. Asia Council, Cambridge, U.K.: BirdLife International.

Collar, N. J. (1985) The world status of the Great Bustard. Bustard Stud. 2: 1-20. 
Collar, N. J. and Goriup, P. D. (1980) The Conservation of the Great Bustard in Portugal. ICBP Bustard Group Working Report. Cambridge, U.K.: ICBP.

Cortés, J. E., Finlayson, J. C., Mosquera, M. A. and García, E. F. J. (1980) The birds of Gibraltar. Gibraltar Bookshop.

Cramp, S. and Simmons, K. E. L. (1980) Handbook of the birds of Europe, the Middle East and North Africa, II. Oxford: Oxford University Press.

Del Hoyo, J., Elliott, A. and Sargatal, J. (1996) Handbook of the birds of the world, 3: Hoatzin to Auks. Barcelona: Lynx Edicions.

Direction des Routes et de la Circulation Routière (undated) Plan of the Sidi-el-YahmaniTangier section of Autoroutes.

Dornbusch, M. (1987) Zur Dispersion der Großtrappe (Otis tarda). Ber. Vogelwarte Hiddensee (8): 49-54.

El Ghazi, A. and Franchimont, J. (1998-99) Chronique ornithologique du G.O.M.A.C. pour 1997. Porphyrio 10-11 (1/2): 60-253.

Glutz von Blotzheim, U. N., Bauer, K. M. and Bezzel, E. (1973) Handbuch der Vögel Mitteleuropas, Vol. 5: Galliformes und Gruiformes. Frankfurt/Main: Akademische Verlag.

Goriup, P. (1994) Great Bustard Otis tarda. Pp. 240-241 in M. G. Tucker and M. F. Heath, eds. Birds in Europe: their conservation status. Cambridge, U.K.: BirdLife International (BirdLife Conserv. Ser. 3).

Goriup, P., ed. (1983) The Houbara Bustard in Morocco. Report of the Al-Areen/ICBP March 1982 Preliminary Survey. Cambridge, U.K.: ICBP.

Hellmich, J. (1987) Apuntes metodológicos sobre censos de avutardas (Otis tarda L.). Conference, I Congr. Int. Aves Esteparias, León, Spain.

Hellmich, J. (1990) La población de avutardas de las áreas de Sierra de Fuentes y de Torrecillas de la Tiesa (Cáceres). Pp. 72-80 in J. C. Alonso and J. A. Alonso, ed. Parámetros demográficos, selección del hábitat y distribución de la Avutarda (Otis tarda) en tres regiones españolas. ICONA (Colección Técnica).

Hellmich, J. (1991a) Sobre metodología de censos de Avutardas (Otis tarda L.) en España. Alytes monogr. 2: 27-38.

Hellmich, J. (1991b) La Avutarda en Extremadura: Distribución, valoración de zonas, movimientos interzonales. Alytes monogr. 2: 9-26.

Hellmich, J. (1991c) Sobre la selección del hábitat de la Avutarda (Otis tarda L.) en una localidad extremeña. Alytes monogr. 2: 39-114.

Hellmich, J. (1992a) Gutachten "Auswirkungen der Schnellbahnverbindung HannoverBerlin auf die Grosstrappenpopulation bei Buckow und erfoderliche Schutzmassnahmen". Erstellt im Auftrage der Planungsgesellschaft Schnellbahnbau Hannover-Berlin $\mathrm{mbH}$.

Hellmich, J. (1992b) Impacto del uso de pesticidas sobre las aves: el caso de la Avutarda. Ardeola 39(2): 7-22.

Hellmich, J. (1999) The Great Bustard Otis tarda L. in Morocco 1998. The International Foundation for Conservation and Development of Wildlife. Inezgane. Unpublished report.

Hellmich, J. and Idaghdour, Y. (2001) The Great Bustard Otis tarda L. in Morocco 19982000 with a note on Little Bustards Tetrax tetrax in the Great Bustard areas. The International Foundation for Conservation and Development of Wildlife. Inezgane. Unpublished report.

Hellmich, J., Dawson, B., Idaghdour, Y. and McCormick, P. (undated) The current status of the Great Bustard Otis tarda in Morocco. IFCDW bi-annual report 1998-1999: 56-59.

Hidalgo de Trucios, S. (1990) World status of the Great Bustard (Otis tarda) with special attention to the Iberian populations. Misc. Zool. 14: 167-180.

Hidalgo de Trucios, S. \& Carranza, J. (1990) Ecologia y comportamiento de la Avutarda (Otis tarda L.). Cáceres: Universidad de Extremadura. 
Hollom, P. A. D., Porter, R. F., Christensen, S. and Willis, I. (1988) Birds of the Middle East and North Africa. Calton, U.K.: Poyser.

Johnsgard, P. A. (1991) Bustards, hemipodes and sandgrouse: birds of dry places. Oxford: Oxford University Press.

Kollar, H. P. (1996) Action plan for the Great Bustard (Otis tarda) in Europe. Pp. 245-260 in B. Heredia, L. Rose and M. Painter: Globally threatened birds in Europe: action plans. Council of Europe.

Lucio, A. and Purroy, F. J. (1990) La población de Avutardas de la provincia de León. Pp. 53-58 in J. C. Alonso and J. A. Alonso, ed. Parámetros demográficos, selección de hábitat y distribución de la Avutarda (Otis tarda) en tres regiones españolas. ICONA-F.E.P.M.A. (Colección técnica).

Moroccan Ministry of Agriculture (1942-1996) Carte du Maroc, 1:100.000 and 1:50.000.

Otero, C. (1977) Pro y contra la supervivencia de la avutarda. Trofeo 8 (85): 18-20.

Pineau, J. and Giraud-Audine, M. (1977) Notes sur les oiseaux nicheurs de l'extrème nordouest du Maroc: Reproduction et mouvements. Alauda 45: 75-104.

Pineau, J. and Giraud-Audine, M. (1979) Les oiseaux de la Peninsule Tingitane. Trav. Inst. Sci. Ser. Zool. 38. (Rabat)

Potapov, R. L. and Flint, V. E. (1989) Handbuch der Vögel der Sowjetunion, 4. Wittenberg.

Schollaert, V. and Franchimont, J. (1995) Chronique ornithologique du G.O.M.A.C. pour 1994. Porphyrio 7 (1/2): 99-146.

Schollaert, V. and Franchimont, J. (1996) Chronique ornithologique du G.O.M.A.C. pour 1995. Porphyrio 8 (1/2): 94-150.

Schollaert, V., Moumni, T,. Fareh, M., Gambarotta, C., Pascon, J. and Franchimont, J. (1994) Chronique ornithologique du G.O.M.A.C. pour 1993. Porphyrio 6 (2): 1-108.

Telleria, J. L. (1981) La migración de las aves en el Estrecho de Gibraltar, II: Aves no planeadoras. Madrid: Universidad Complutense.

Thévenot, M., Beaubrun, P., Baouab, R. E. and Bergier, P. (1982) Compte rendu d'ornithologie marocaine, Année 1981. Documents de l'Institut Scientifique, 7 (Rabat).

Urban, E. K., Fry, C. H. and Keith, S. (1986) The birds of Africa, II. Gamebirds to Pigeons. London: Academic Press.

JOACHIM HELLMICH

IFCDW D.E.R.S. (The Desert Ecology Research Station), P.O. Box 554, 52000 Er-Rachidia, Morocco

YOUSSEF IDAGHDOUR

IFCDW Agadir, P.O. Box 116, Inezgane, Morocco

Received 27 June 2001; revision accepted 2 November 2001. 